\title{
LAPORAN KASUS KERACUNAN Chlorophyllum cf. molybdites DI SURABAYA, INDONESIA
}

\section{Poisoning case report of Chlorophyllum cf. molybdites in Surabaya, Indonesia}

\author{
Ivan Permana Putra \\ Divisi Mikologi, Departemen Biologi, FMIPA, Institut Pertanian Bogor, Bogor, Indonesia \\ Doi: $10.37195 /$ jac.v3i1.120
}

\section{KORESPONDENSI \\ Telepon: +62-821-2273-3307 \\ E-mail: ivanpermanaputra@apps.ipb.ac.id \\ JEJAK PENGIRIMAN}

Diterima: 20 Jan 2021

Revisi Akhir: 10 Feb 2021

Disetujui: 18 Feb 2021

\section{KEYWORDS}

Poisoning, Wild mushroom,

C. molybdites, Surabaya

\section{KATA KUNCI}

Keracunan, Jamur liar, C. molybdites, Surabaya

\section{ABSTRACT}

Wild mushrooms are one of the agricultural commodities used as food by Indonesian. However, the risk of poisoning can occur due to the morphology which often similar between edible and poisonous mushrooms. One family consumed wild mushroom which found around their residential area in Surabaya. The macrofungi grew on the grass near the 'sengon' trees around it. A few hours later, all of them experienced vomiting and diarrhea. The entire family rushly evacuated to the nearest hospital and received treatment. The blood tests and computed tomography (ct) scan of the abdomen showed no serious effect in all victims. The mushroom which caused poisoning then documented completely. The identification results using several macroscopic characters confirmed the macrofungi as Chlorophyllum cf. molybdites. This mushroom is known as in the category of $V$ poisonous mushrooms which cause irritation of the digestive tract. This report indicates the need for a better understanding of the wild mushrooms identification for consumption. This is one of the approach to prevent wild mushroom poisoning in Indonesia.

Jamur liar merupakan salah satu komoditas pertanian yang dimanfaatkan sebagai bahan pangan oleh masyarakat Indonesia. Namun risiko keracunan bisa terjadi karena morfologi yang seringkali terlihat mirip antara jamur yang dapat dimakan dan yang beracun. Satu keluarga mengkonsumsi jamur liar yang ditemukan di sekitar pemukiman rumahnya di Surabaya. Jamur tersebut tumbuh pada rerumputan dengan beberapa pohon sengon di sekitarnya. Beberapa jam kemudian semuanya mengalami gejala muntah dan diare. Seluruh anggota keluarga tersebut kemudian dievakuasi ke rumah sakit terdekat dan mendapatkan pengobatan. Hasil cek darah dan computed tomography (ct) scan abdomen menunjukkan tidak ada efek yang serius pada semua korban. Jamur yang menyebabkan keracunan didokumentasikan dengan lengkap. Hasil identifikasi dengan menggunakan karakter makroskopik mengkonfirmasi jamur tersebut sebagai Chlorophyllum cf. molybdites. Jamur ini termasuk dalam kategori jamur beracun tipe $\mathrm{V}$ yang menyebabkan iritasi saluran pencernaan. Laporan ini mengindikasikan perlunya pemahaman yang baik terkait pengenalan jamur liar untuk dikonsumsi. Hal tersebut merupakan salah satu cara untuk mencegah terjadinya keracunan jamur liar di Indonesia. 


\section{PENDAHULUAN}

Hingga saat ini belum diketahui dengan pasti berapa jumlah spesies jamur yang ada di dunia. Blackwell (2011) mengestimasikan terdapat sekitar 1,5 juta spesies jamur yang ada di seluruh dunia. Jamur mampu menempati berbagai relung ekologi (Putra, Mardiyah, Amalia, \& Mountara, 2017; Putra, Sitompul, \& Chalisya, 2018) dan juga sangat mudah ditemukan di sekitar area pemukiman penduduk (Putra \& Astuti, 2021). Dari total perkiraan jumlah jenis jamur yang ada, sebanyak 2000 jenis di antaranya dimanfaatkan sebagai bahan pangan dan bahan bioaktif untuk medis (Boa, 2004; Lima, Costa-Fortes, Garbi-Novaes, \& Percário, 2012). Putra (2020d) melaporkan bahwa jamur liar merupakan salah satu komoditas pertanian musiman yang memiliki nilai ekonomi sehingga sering dicari oleh mayarakat lokal ketika merambah. Selain itu, beberapa jamur liar yang tumbuh di sekitar lokasi kegiatan antropogenik merupakan jenis yang dapat dimakan atau edible (Putra, Amelya, Veronica, \& Kurnianto, 2020) dan juga beracun (Putra, 2020a; 2020b). Hal ini menyebabkan kasus keracunan jamur merupakan salah satu ancaman kesehatan serius bagi masyarakat dan penggiat jamur.

Genus Chlorophyllum merupakan salah satu jamur yang paling banyak ditemukan tumbuh di sekitaran area tempat tinggal manusia (Arora, 1986). Jenis Chlorophyllum molybdites diketahui merupakan penyebab utama kasus keracunan jamur sepanjang masa di berbagai negara (Lehmann \& Khazan, 1992). Jamur ini tergolong ke dalam jamur penyebab keracunan kategori $\mathrm{V}$ dan menyerang sistem pencernaan (White et al., 2019). Umumnya, korban keracunan C. molybdites menunjukkan gejala sakit kepala, mual, muntah, diare, dan sesak napas (Bijeesh, Vrinda, \& Pradeep, 2017). Selain itu, jamur ini seringkali sulit dibedakan dengan Agaricus, Lepiota, Macrolepiota, dan Amanita karena morfologinya yang mirip (Putra, 2020c).

Walaupun kasus keracunan jamur liar telah beberapa kali dilaporkan (Putra, 2020a; 2020b), Indonesia belum memiliki pangkalan data yang baik mengenai jamur-jamur penyebab keracunan. Sebagian besar informasi keracunan jamur ditulis pada media cetak atau elektronik namun dengan data yang sangat minim. Hal ini mengindikasikan perlunya edukasi dan transfer ilmu mikologi yang lebih baik kepada masyarakat. Laporan ini bertujuan untuk memberikan informasi terkait kasus keracunan C. molybdites, cara pengenalan/ identifikasi, dan resiko toksisitasnya. Diseminasi informasi mikologi adalah salah satu upaya yang dapat ditempuh guna mencegah terjadinya keracunan jamur liar di Indonesia.

\section{METODE}

\section{Pengumpulan Data dan Identifikasi Jamur}

Informasi mengenai keracunan jamur diperoleh dari keluarga korban pada 21 Desember 2020. Keluarga korban merupakan penggiat jamur yang tergabung dalam Komunitas Pemburu Jamur Indonesia. Jamur penyebab keracunan didokumentasikan secara lengkap. Deskripsi jamur dibuat dengan menggunakan berbagai karakter makroskopik merujuk pada penjelasan Putra et al. (2018) dengan modifikasi. Karakter identifikasi makroskopik meliputi: cara tumbuh, bentuk tubuh buah, hygrophanous (perubahan tingkat kebasahan), warna tudung (cap ) ketika tubuh buah muda dan tua, diameter cap, bentuk atas dan bawah pada cap, permukaan cap, tepian cap, margin (tepian) cap, tingkat kebasahan, tipe himenofor (lamela, pori, gerigi) meliputi: cara menempel pada tangkai (stipe), jarak antar baris, dan margin. Karakter lain yang diobservasi adalah bentuk stipe, warna stipe (ketika muda dan tua), permukaan stipe, posisi penempelan pada cap,tipe penempelan stipe pada substrat, penampang stipe, keberadaan rhizomorph, tudung parsial, tudung universal, tekstur tubuh buah, bau, rasa serta informasi penggunaannya sebagai bahan pangan (dikonsumsi atau tidak) melalui diskusi dengan masyarakat setempat untuk mendapatkan informasi mengenai pemanfaatan jamur yang ditemukan. Jamur diidentifikasi hingga ke tingkat genus dan spesies (jika memungkinkan) dengan karakteristik makroskopis menggunakan beberapa acuan identifikasi di antaranya Largent (1973), Arora (1986), dan Imazeki, Otani, \& Hongo (1988). Posisi taksonomi dan identitas terbaru dari 
jamur yang ditemukan mengikuti ketentuan dari indexfungorum.

\section{HASIL DAN PEMBAHASAN}

\section{Kasus keracunan Chlorophyllum Cf. Molybdites}

Satu keluarga yang terdiri atas ayah, ibu, dan anak kecil dilarikan ke sebuah rumah sakit di Kota Surabaya, Jawa Timur. Keluarga tersebut mengalami sakit perut, muntah, dan diare setelah mengkonsumsi jamur liar yang ditemukan di sekitar rumahnya. Sebelumnya korban telah diberikan pertolongan pertama berupa air kelapa dan susu murni. Pemeriksaan Serum Glutamic Oxaloacetic Transaminase (SGOT) dan Serum Glutamic Pyruvic Transaminase (SGPT) mengkonfirmasi kondisi yang masih normal pada seluruh korban. Selain itu, hasil cek darah dan computed tomography (ct) scan abdomen yang dilakukan, menunjukkan tidak ada efek yang serius pada semua korban. Oleh dokter, korban diberikan obat berupa sukralfat, omeprazol, dan attapulgite dan diijinkan untuk pulang. Satu hari kemudian, semua korban telah beraktifitas seperti biasanya namun masih merasakan gejala perut terasa penuh (begah), sesak dada, dan sempit tenggorokan. Empat puluh delapan jam kemudian, kondisi kesehatan seluruh korban mulai membaik dan tidak merasakan gejala sakit pada tubuhnya. Korban keracunan mengalami trauma untuk memakan jamur kembali.

\section{Identifikasi Chlorophyllum cf. molybdites penyebab keracunan}

Jamur penyebab keracunan ditampilkan pada Gbr. 1A-E, sedangkan Gbr. 1F merupakan informasi tambahan untuk melengkapi karakter yang bisa dijadikan sebagai acuan oleh masyarakat di masa mendatang. Jamur beracun pada tulisan ini memiliki ciri sebagai berikut: jamur tumbuh berkelompok dalam jumlah terbatas dan pada jarak tertentu. Jamur tumbuh pada rerumputan dan semak dengan vegetasi pohon sengon di sekitarnya. Tubuh buah terdiri atas tudung (pileus), berlamela, dan memiliki tangkai sejati (stipe). Tudung berwarna putih hingga krem (Gbr. 1A) dan memiliki umbo (tonjolan) di bagian tengah tudungnya (Gbr. 1A-C). Pileus berbentuk hampir rata (flat) pada tubuh buah dewasa/merekah. Permukaan pileus memiliki ornamen berupa lukaan (sclae) yang tersebar pada jarak terbatas (Gbr. 1B) atau halus tanpa ornamen (Gbr. 1A). Beberapa ornamen pada jamur akan meluruh pada kondisi tertentu seperti saat tercuci air hujan. Tepian tudung sedikit bergerigi (crenate) dan margin yang rata (tidak melengkung ke dalam atau ke luar). Jamur ini memiliki tipe himenofor berupa lamela (Gbr. 1C-F) dengan warna krem kehijauan (olive green) (Gbr. 1A; C) yang semakin lama menjadi pekat seiring perkembangan tubuh buah (Gbr. 1F). Lamela tidak menempel pada tangkai (free), jarak antar bilah padat, dengan margin rata (blade-shaped). Tangkai berbentuk tabung/ silinder dengan ukuran seragam dari atas hingga ke bagian basal, berwarna krem dengan sedikit lapisan kecoklatan, menempel pada tudung pada posisi central, dan menempel pada substrat dengan tipe basal tomentum. Tangkai memiliki cincin (ring) dengan posisi mendekati tudung (superior). Tekstur tubuh buah berdaging tanpa bau yang khas.

Posisi taksonomi C. molybdites mengikuti aturan dari indexfungorum adalah: Fungi, Basidiomycota, Agaricomycotina, Agaricomycetes, Agaricomycetidae, Agaricales, Agaricaceae. Korban keracunan menyampaikan bahwa jamur yang mereka ambil dari rerumputan belum pernah mereka konsumsi sebelumnya. Jika dilihat secara sekilas dari tampak atas tudungnya, jamur ini sulit dibedakan dengan Agaricus, Lepiota, Macrolepiota, dan Amanita, tanpa melihat bagian bawah tudungnya (Arora, 1986; Bijeesh et al., 2017; Putra, 2020c) terutama oleh masyarakat awam. Karakter kunci dari $C$. molybdites adalah keberadaan deposit spora yang berwarna krem kehijauan saat muda dan hijau gelap (olive green) saat tua. Salah satu cara untuk mengingat jamur ini adalah nama Chlorophyllum yang diambil dari kata klorofil / hijau. Selain itu, cara yang paling baik untuk mengecek warna spora adalah dengan membuat jejak spora (Gbr. 1F). Di banyak negara, jamur ini disebut sebagai the vomitter karena beberapa kali menyebabkan keracunan yang menyerang sistem pencernaan (lambung). Pada tubuh buah yang masih muda, deposit spora berwarna hijau sangat tipis dan tidak pada seluruh bagiannya, sehingga diperlukan ketelitian dan kehati-hatian saat mengobservasi $C$. molybdites. 
Hingga saat ini, Indonesia belum mempunyai pangkalan data yang mumpuni terkait kasus keracunan jamur. Sebagian besar informasi keracunan jamur berasal dari media massa dan hanya sedikit dari publikasi ilmiah berupa jurnal (Putra, 2020a; 2020b). Hambatan utama dalam mengidentifikasi jamur penyebab keracunan dari media cetak ataupun elektronik adalah minimnya informasi (dokumentasi) minimal karakter yang bisa digunakan untuk identifikasi jamur. Sebagian besar jamur memiliki morfologi yang mirip antara satu jamur dengan jamur lainnya, sehingga diperlukan beberapa karakter kunci dalam mengidentifikasi jamur dengan benar (Putra et al., 2018). Walaupun dokumentasi jamur pada tulisan ini dilengkapi dengan berbagai karakter lengkap makroskopik, penamaan hingga ke level spesies masih diberikan penanda cf. karena perlu dilakukan observasi mikroskopis untuk mengkonfirmasi identitas spesies jamur tersebut. Putra (2020c) melaporkan jenis jamur ini mudah ditemukan di sekitar pekarangan rumah, mulai dari daerah rerumputan hingga bersemak. Hal ini mengimplikasikan perlunya kehati-hatian terutama saat merambah dan mengkonsumsi jamur liar yang ada di sekitar pemukiman. Hal ini dikarenakan budaya merambah jamur liar untuk konsumsi telah menjadi bagian dari keseharian masyarakat Indonesia (Putra dan Hafazallah, 2020).

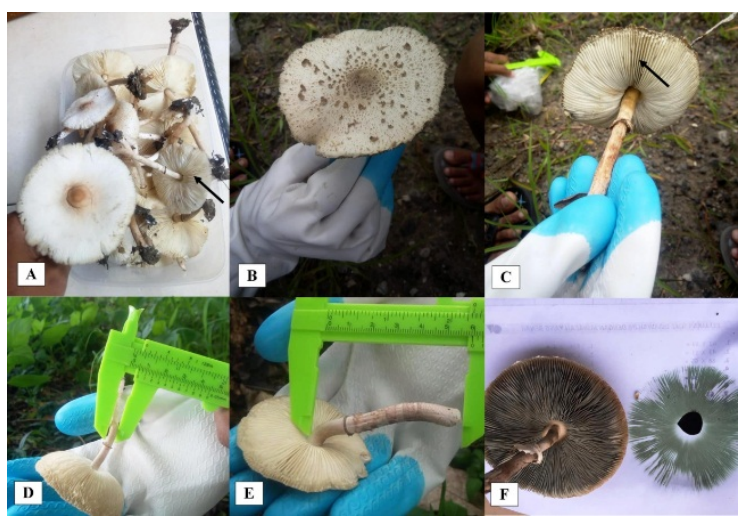

Gbr 1. Karakter makroskopik Cholorophyllum cf. molybdytes penyebab keracunan. A: Tubuh buah yang dikonsumsi. B: Permukaan tudung yang masih memiliki ornamen. C: Deposit spora berwarna hijau olive pada lamela. D-E: Bagian bawah tudung yang dilengkapi tangkai dengan cincin. F: Jejak spora dari tubuh buah yang telah dewasa. A-E: Dokumentasi Mincu KM. F: Dokumentasi Ferry Augustinus.

\section{Aspek Toksisitas Chlorophyllum cf. molybdites}

Seluruh anggota keluarga yang mengalami keracunan jamur ini menunjukkan gejala mual, muntah, dan diare. Gejala tersebut muncul setelah beberapa jam mengkonsumsi jamur liar tersebut. White et al. (2019) melaporkan bahwa jenis jamur ini merupakan kelompok jamur beracun tipe $V$ yang menyebabkan iritasi pada saluran pencernaan, terutama lambung. Contoh jenis lainnya dari jamur beracun tipe ini adalah Entoloma sinuatum dan Tricholoma pardalotum. Walaupun umumnya tidak sampai menyebabkan kematian, efek yang dihasilkan dari kelompok jamur tipe $\mathrm{V}$ ini sangat berbahaya untuk kesehatan. Dampak sekunder dari jamur tipe $\mathrm{V}$ ini adalah dehidrasi yang bisa dialami oleh korban keracunan. Namun korban keracunan pada tulisan ini tidak mengalami hal tersebut karena mendapatkan pertolongan pertama yang baik dan segera dibawa ke rumah sakit terdekat. Bijeesh et al. (2017) juga melaporkan bahwa C. molybdites mengandung racun protein polimerik dan menyebabkan keracunan terhadap 2 orang di Kerala (India). Korban tersebut harus dirawat secara intensif selama 2 hari di rumah sakit.

Lehmann dan Khazan menyebutkan bahwa $C$. molybdites merupakan salah satu jamur penyebab keracunan terbanyak sepanjang masa. Mereka juga melaporkan bahwa jamur tersebut telah seringkali menyebabkan keracunan di Amerika Serikat. Sementara itu, selama 10 tahun terakhir (2010-2020), Putra (2021) melaporkan bahwa telah terjadi sejumlah 4 kasus keracunan Chlorophyllum cf. molybdites di Indonesia dengan jumlah korban sebanyak 34 orang dan tanpa ada yang meninggal dunia. Beberapa kasus keracunan jamur liar di Indonesia diketahui sampai menyebabkan kematian pada korbannya Putra (2020a; 2020b). Umumnya korban keracunan jamur di Indonesia, salah mengenali jamur yang biasa dikonsumsi karena kurangnya pengalaman dan pengetahuan mengenai jamur beracun dan jamur edible yang ada di Indonesia. Transfer ilmu mikologi dan edukasi kepada masyarakat merupakan salah satu cara yang dapat dilakukan untuk mencegah terjadinya kasus keracunan jamur di masa mendatang. 


\section{KESIMPULAN}

Jamur liar merupakan salah satu bahan pangan favorit yang dicari masyarakat ketika merambah. Namun beberapa jamur memiliki kandungan racun pada tubuh buahnya. Chlorophyllum cf. molybdites menyebabkan keracunan pada satu keluarga di Surabaya. Korban mengalami muntah, sakit perut, diare dan mendapatkan penanganan yang cepat di rumah sakit terdekat. Hasil pengecekan menunjukkan bahwa korban tidak mengalami gejalasa sakit yang serius. Jamur penyebab keracunan diidentifikasi dan dibuatkan deskripsi sebagai media diseminasi informasi mikologi guna mencegah kejadian yang sama berulang kembali di Indonesia.

\section{PENGHARGAAN}

Penulis mengucapkan terima kasih kepada Komunitas Pemburu Jamur Indonesia yang telah membantu penulisan ini.

\section{DAFTAR PUSTAKA}

Arora, D. (1986). Mushrooms Demystified: a Comprehensive Guide to the Fleshy Fungi (2nd ed.). Berkeley: Ten Speed Press.

Bijeesh, C., Vrinda, K. B., \& Pradeep, C. K. (2017). Mushroom poisoning by Chlorophyllum molybdites in Kerala. J. Mycopathol. Res. 54(4), 477-483.

Blackwell, M. (2011). The fungi: 1, 2, 3 ... 5.1 million species? American Journal of Botany, 98(3), 426-438. doi: 10.3732/ajb.1000298.

Boa, E. (2004). Wild Edible Fungi: a Global Overview of Their Use and Importance to People. Rome: FAO.

Imazeki, R., Otani, Y., \& Hongo, T. (1988). Fungi of Japan. Tokyo: Yama-Kei Publishers.

Largent, D. L. (1973). How to Identify Mushrooms to Genus I: Macroscopic Features. USA: Eureka (CA), Mad River Press Inc.

Lehmann, P. F., \& Khazan, U. (1992). Mushroom poisoning by Chlorophyllum molybdites in the Midwest United States. Mycopathologia, 118(1), 3-13. https://doi .org/10.1007/BF00472564.

Lima, A. D. L., Costa-Fortes, R., Garbi-Novaes, M. R. C., \& Percário, S. (2012). Poisonous mushrooms: a review of the most common intoxications. Nutr Hosp. 27, 402-408. doi: 10.3305/nh.2012.27.2.5328.
Putra, I. P. (2020a). Kasus keracunan Inocybe sp. di Indonesia. Paper presented at Prosiding Seminar Nasional Biologi di Era Pandemi COVID-19, Gowa, Indonesia. http://journal.uin-alauddin.ac.id/index. $\mathrm{php} / \mathrm{psb} /$ article/download/15727/9610

Putra, I. P. (2020b). Scleroderma spp. in Indonesia: Poisoning case and potential utilization. Justek: Jurnal Sains dan Teknologi, 3(2), 37-45. http://dx.doi.org/ 10.31764/justek.v3i2.3517.

Putra, I. P. (2020c). Studi taksonomi dan potensi beberapa jamur liar di Pulau Belitong. Justek: Jurnal Sains dan Teknologi, 3(1), 24-31. http://dx.doi.org/10.31764/ justek.v3i1.3534.

Putra, I. P. (2020d). The potency of some wild edible mushrooms with economic value in Belitong Island, The Province of Bangka Belitung. Jurnal Wasian, 7(2), 121-135. http://dx.doi.org/10.20886/jwas.v7i2.6109

Putra, I. P. (2021). Kasus-kasus keracunan jamur liar di Indonesia. Biosel: Biology Science and Education. (Article in Press).

Putra, I. P., \& Astuti, M. (2021). Catatan Beberapa Jamur Liar yang Tumbuh di Sekitar Pemukiman Penduduk. Quagga, 13(1), 48-59. https://doi.org/10.25134/ quagga.v13i1.3617.

Putra, I. P., \& Hafazallah, K. (2020). Catatan Komunitas Pemburu Jamur Indonesia: Kolaborasi Lintas Profesi dan Generasi Mengenai Etnomikologi Jamur-Jamur Indonesia. Sukabumi: Haura Publishing.

Putra, I. P., Amelya, M. P., Veronica, S., \& Kurnianto, M. S. (2020). Fantastic fungi around us: a case study of IPB University Campus Forest. Jurnal Pena Sains, 7(2), 6882. http://dx.doi.org/10.21107/jps.v7i2.67 53.

Putra, I. P., Mardiyah, E., Amalia, N. S., \& Mountara, A. (2017). Biodiversity of Mushroom from litter and soil in Ujung Kulon National Park, Indonesia. Jurnal Sumberdaya HAYATI, 3(1), 1-7.

Putra, I. P., Sitompul, R., \& Chalisya, N. (2018). Diversity and potency of macro fungi at Mekarsari Tourist Parkwest Java. AlKauniyah: Jurnal Biologi, 11(2), 133-150. http://dx.doi.org/10.15408/kauniyah.v11i 2.6729 .

White, J., Weinstein, S. A., De Haro, L., Bédry, R., Schaper, A., Rumack, B. H., \& Zilker, T. 
(2018). Mushroom poisoning: a proposed new clinical classification. Toxicon, 157, 5365. http://dx.doi.org/10.1016/j.toxicon. 2018.11.007. 